\title{
DIVERSIFIKASI USAHA DAN MANAJEMEN LABA DENGAN PENDEKATAN CONDITIONAL REVENUE MODEL
}

\author{
Matthew Haryanto dan Lina \\ Jurusan Akuntansi, Fakultas Ekonomi, Universitas Pelita Harapan \\ Email: lina.fe@uph.edu
}

\begin{abstract}
Generally, go public companies are belong to large-scale companies or even international ones. Mostly those companies have more than one business divisions, therefore the financial reports might be published in more than one segments. According to Financial Accounting Standard 5, the company financial reports can be distinguished between geographical segments and operating segments. This study aims to give the empirical evidence about the influence of the business diversification towards earnings management. The amount of the geography segments and the operating segments are used as proxy to represent the business diversification. The earnings management is measured by conditional revenue model. The data is collected from the company annual reports by accessing through Indonesia Stock Exchange website for period 2011-2013. The sampling method used is purposive sampling. Data analysis used multiple linear regressions. The result of the study shows that the geography segments have no influence on the earnings management, meanwhile the operating segments have positive influence on earnings management.
\end{abstract}

Keywords: business diversification, operating segments, geography segments, and earnings management

\begin{abstract}
Abstrak: Umumnya perusahaan go public tergabung dalam perusahaan berskala besar atau bahkan yang internasional. Sebagian besar perusahaan tersebut memiliki lebih dari satu divisi bisnis, oleh karena itu laporan keuangan dapat dipublikasikan di lebih dari satu segmen. Menurut Standar Akuntansi Keuangan 5, laporan keuangan perusahaan dapat dibedakan antara segmen geografis dan segmen operasi. Penelitian ini bertujuan untuk memberikan bukti empiris tentang pengaruh diversifikasi usaha terhadap manajemen laba. Jumlah segmen geografi dan segmen operasi digunakan sebagai proxy untuk mewakili diversifikasi usaha. Manajemen laba diukur dengan model pendapatan bersyarat. Data dikumpulkan dari laporan tahunan perusahaan dengan mengakses melalui situs web Bursa Efek Indonesia untuk periode 2011-2013. Metode pengambilan sampel yang digunakan adalah purposive sampling. Analisis data menggunakan regresi linier berganda. Hasil penelitian menunjukkan bahwa segmen geografi tidak berpengaruh terhadap manajemen laba, sedangkan segmen operasi berpengaruh positif terhadap manajemen laba.
\end{abstract}

Kata kunci: diversifikasi usaha, segmen operasi, segmen geografi, dan manajemen laba

\section{PENDAHULUAN}

Manajemen laba merupakan salah satu fenomena yang paling sering diteliti dalam kaitannya dengan agency problem. Manajemen laba adalah pemilihan kebijakan akuntansi oleh manajer dari Standar Akuntansi Keuangan yang ada dan secara alamiah dapat 
memaksimalkan utilitas mereka dan atau nilai pasar perusahaan (Scott, 2011). Manajemen laba tidak selalu mengarah pada manipulasi laba yang menunjukkan indikasi kecurangan yang dilakukan oleh pihak manajemen, akan tetapi lebih mengarah kepada usaha manajemen untuk menaikkan atau menurunkan laba sesuai batasan yang diperbolehkan, artinya dengan menggunakan metode-metode akuntansi yang dianggap paling menguntungkan perusahaan.

Menurut Sulistyanto (2008), manajemen laba dilakukan dengan mempermainkan komponen-komponen akrual dalam laporan keuangan, sebab pada komponen akrual dapat dilakukan permainan angka melalui metode akuntansi yang digunakan sesuai dengan keinginan orang yang melakukan pencatatan dan penyusunan laporan keuangan. Komponan akrual merupakan komponen yang tidak memerlukan bukti kas secara fisik sehingga mempermainkan besar kecilnya komponen akrual tidak harus disertai dengan kas yang diterima atau dikeluarkan perusahaan (Sulistyanto, 2008).

Banyak faktor yang dapat memicu terjadinya manajemen laba, salah satunya adalah diversifikasi usaha. Diversifikasi usaha merupakan upaya penganekaragaman unit usaha yang dilakukan perusahaan dalam rangka memperluas pasar, baik dalam bidang usaha atau produk maupun lokasi geografis untuk memaksimalkan keuntungan atau laba yang diperoleh suatu perusahaan. Dengan bertambahnya unit usaha baik produk maupun lokasi geografis dalam suatu perusahaan, maka akan meningkatkan kompleksitas dalam perusahaan itu sendiri. Meningkatnya kompleksitas perusahaan inilah yang memicu terjadinya manajemen laba.

Dalam penelitian ini, diversifikasi usaha yang dimaksud diukur dengan menggunakan jumlah segmen yang dimiliki oleh perusahaan. Semakin banyak segmen yang dimiliki oleh suatu perusahaan, maka semakin kompleks perusahaan tersebut. Menurut Scott (2011), pengungkapan tentang segmen akan mempersulit manajemen menyembunyikan kinerja buruk dari salah satu segmen dengan kinerja bagus dari segmen lainnya. Semakin rinci suatu pengungkapan maka akan semakin tinggi kualitas pengungkapan tersebut, dan analis akan mempunyai lebih banyak informasi yang dibutuhkan sehingga dapat melakukan analisa lebih baik.

Selain berguna bagi analis, investor, pemangku kepentingan, dan pihak lainnya, dengan menerbitkan pelaporan segmental perusahaan juga sekaligus menjaga kelangsungan hidupnya (going concern) karena analisa keuangan dapat dilakukan lebih jelas dan rinci. Seperti misalnya, dapat mengeliminasi segmen tertentu yang dianggap tidak memberikan keuntungan berarti atau malah memberikan kontribusi rugi terhadap agregat perusahaan. Di Indonesia, pelaporan segmental diterbitkan perusahaan sesuai dengan PSAK nomor 5 (lima), revisi terakhir pada tahun 2014 yang terdiri dari segmen geografis dan operasi.

Akan tetapi tidak berarti bahwa setiap industri yang memiliki segmen operasi atau geografis lebih dari satu dapat melaporkan keuangannya secara segmental, namun harus mengacu pada kriteria segmen dilaporkan (PSAK, 2014), yaitu; 1). Telah teridentifikasi sebagai segmen operasi atau hasil dari dua agregasi atau lebih, 2). Melebihi ambang batas (salah satu), 2.1. Pendapatan lebih dari sepuluh persen dari pendapatan total internal dan eksternal, 2.2. Laba rugi absolut lebih sepuluh persen dari laba rugi absolut dari (mana yang lebih besar) gabungan segmen yang laba atau gabungan segmen yang rugi, 2.3. Aset lebih sepuluh persen aset gabungan segmen operasi, 3). Jika tidak memenuhi ambang batas dapat dipertimbangkan yaitu jika manajemen percaya informasi tersebut berguna bagi pengguna, 4). Yang tidak memenuhi ambang batas dapat digabung jika memenuhi 
kriteria agregasi, 5). Jika yang dilaporkan kurang dari tujuh puluh lima persen dari pendapatan entitas yaitu tambahan segmen diidentifikasi (walau tidak memenuhi kriteria), 6). Segmen operasi lain yang tidak dilaporkan digabungkan dan diungkapkan dalam kategori "semua segmen lain".

Beberapa penelitian yang ada telah mencoba menguji keterkaitan antara diversifikasi usaha dan manjemen laba. Akan tetapi, dari penelitian terdahulu yang sudah dilakukan, belum ada yang memberikan kesimpulan yang bersifat konklusif dan minimnya penelitian yang menggunakan data di Indonesia. Penelitian ini tertarik untuk melihat bagaimana pengaruh diversifikasi usaha terhadap manajemen laba pada industri manufaktur di Indonesia.

Penelitian ini juga dilakukan sebagai pengembangan dari penelitian sebelumnya yaitu Nugraheni (2011) di mana fokus penelitian tersebut adalah terhadap negara-negara Asia yang terdaftar di New York Stock Exchange (NYSE). Nugraheni (2011) menyatakan bahwa negara di wilayah Asia menarik untuk diteliti karena beberapa negara Asia merupakan negara dengan pertumbuhan ekonomi tercepat di dunia yang terus berkembang di tengah persaingan global. Fokus penelitian ini adalah terhadap perusahaan manufaktur yang terdaftar di Bursa Efek Indonesia (BEI).

Berdasarkan latar belakang yang telah diuraikan sebelumnya, maka rumusan masalah dalam penelitian ini adalah (1) Apakah pelaporan segmen operasi memiliki pengaruh positif terhadap manajemen laba? (2) Apakah pelaporan segmen geografis memiliki pengaruh positif terhadap manajemen laba.

Tujuan penelitian yang ingin dicapai adalah untuk mendapatkan bukti empiris mengenai pengaruh positif pelaporan segmen operasi dan pelaporan segmen geografis terhadap manajemen laba.

\section{KAJIAN TEORI}

Teori Keagenan (Agency Theory). Teori ini menekankan pada hubungan antara pemilik (principal) dan pengelola atau manajemen (agent). Dalam hal ini pengelola dipilih langsung oleh pemilik untuk bekerja demi kepentingan pemilik. Oleh sebab itu, pengelola mempertanggungjawabkan semua pekerjaannya kepada pemilik.

Jensen dan Meckling (1976) mendeskripsikan hubungan keagenan sebagai suatu kontrak dimana satu atau lebih orang (prinsipal) memerintah orang lain (agen) untuk melakukan suatu jasa atas nama prinsipal serta memberi wewenang kepada agen membuat keputusan yang terbaik bagi prinsipal. Jika kedua belah pihak tersebut mempunyai tujuan yang sama untuk memaksimumkan nilai perusahaan, maka diyakini agen akan bertindak dengan cara yang sesuai dengan kepentingan prinsipal. Michelson et al. (1995) mendefinisikan keagenan sebagai suatu hubungan berdasarkan persetujuan antara dua pihak, dimana manajemen (agent) setuju untuk bertindak atas nama pihak lain yaitu pemilik (prinsipal). Pemilik akan mendelegasikan tanggungjawab kepada manajemen, dan manajemen setuju untuk bertindak atas perintah atau wewenang yang diberikan pemilik.

Meskipun hubungan antara prinsipal dan agen dilandasi pada kontrak yang ada, akan tetapi agen tidak mungkin bekerja semata-mata hanya untuk kepentingan pemilik. Hal ini tentunya didasari pada keinginan agen dalam mencapai kesejahteraan pribadinya. Informasi dalam teori agensi digunakan untuk mengambil keputusan oleh prinsipal dan agen, serta untuk mengevaluasi dan membagi hasil sesuai kontrak kerja yang telah 
disetujui. Hal inilah yang memotivasi agen untuk menyajikan laporan akuntansi yang seoptimal mungkin untuk meningkatkan kepercayaan prinsipal kepadanya.

Scott (2011) menyatakan apabila beberapa pihak yang terkait dalam transaksi bisnis lebih memiliki informasi daripada pihak lainnya, maka kondisi tersebut dikatakan sebagai asimetri informasi. Hal ini bisa terjadi dalam hubungan antara agen dan prinsipal. Informasi asimetri terjadi ketika adanya informasi yang terdistribusi secara tidak merata antara agen dan prinsipal dan kondisi di mana prinsipal tidak mungkin secara langsung mengawasi agen di setiap waktu. Hal inilah yang memungkinkan agen untuk melakukan perilaku yang tidak semestinya (disfunctional behavior).

Disfunctional behavior ini dapat dilakukan agen dengan cara melakukan manajemen laba. Praktik ini dilakukan untuk memanipulasi angka-angka pada laporan keuangan yang tidak menunjukkan kondisi perusahaan yang sebenarnya, semata-mata untuk mencapai apa yang dikehendaki oleh prinsipal terhadap perusahaannya.

Utami (2005) mengutip pendapat Copeland mendefinisikan manajemen laba sebagai usaha manajemen untuk memaksimumkan atau meminimumkan laba, termasuk perataan laba sesuai dengan keinginan manajer. Sedangkan Scott (2011) membagi cara pemahaman atas manajemen laba menjadi dua, yaitu: 1). Melihatnya sebagai perilaku oportunistik manajer untuk memaksimumkan utilitasnya dalam menghadapi kontrak kompensasi, kontrak utang, dan political costs (opportunistic earnings management) dan 2). Memandang manajemen laba dari perspektif efficient contracting (efficient earnings management), dimana manajemen laba memberi manajer suatu fleksibilitas untuk melindungi diri mereka dan perusahaan dalam mengantisipasi kejadian-kejadian yang tak terduga untuk keuntungan pihak-pihak yang terlibat dalam kontrak. Dengan demikian, manajer dapat mempengaruhi nilai pasar perusahaannya melalui manajemen laba, misalnya dengan membuat perataan laba (income smoothing) dan pertumbuhan laba sepanjang waktu.

Dalam Positive Accounting Theory terdapat tiga faktor pendorong yang melatarbelakangi terjadinya manajemen laba (Watt dan Zimmerman, 1986), yaitu: 1). Bonus Plan Hypothesis. Manajemen akan memilih metode akuntansi yang memaksimalkan utilitasnya yaitu bonus yang tinggi. Manajer perusahaan yang memberikan bonus besar berdasarkan laba lebih banyak menggunakan metode akuntansi yang meningkatkan laba yang dilaporkan. 2). Debt Covenant Hypothesis. Manajer perusahaan yang melakukan pelanggaran perjanjian kredit cenderung memilih metode akuntansi yang memiliki dampak meningkatkan laba (Rahmawati et al. (2006). Hal ini untuk menjaga reputasi mereka dalam pandangan pihak eksternal. 3). Political Cost Hypothesis. Semakin besar perusahaan, semakin besar pula kemungkinan perusahaan tersebut memilih metode akuntansi yang menurunkan laba. Hal tersebut dikarenakan dengan laba yang tinggi pemerintah akan segera mengambil tindakan, misalnya: mengenakan peraturan antitrust, menaikkan pajak pendapatan perusahaan, dan lain-lain.

Diversifikasi Usaha. Perusahaan yang memiliki lebih dari satu, atau beranekaragam unit bisnis, baik secara operasi maupun geografis merupakan perusahaan yang terdiversifikasi. Harto (2005) mendefinisikan diversifikasi perusahaan sebagai bentuk pengembangan usaha dengan cara memperluas jumlah segmen secara bisnis maupun geografis maupun memperluas market share yang ada atau mengembangkan berbagai produk yang beranekaragam. Hal ini dapat dilakukan dengan membuka lini usaha baru, memperluas lini produk yang ada, memperluas wilayah pemasaran produk, membuka kantor cabang, 
melakukan merger dan akuisisi untuk meningkatkan skala ekonomis dan cara yang lainnya.

Pelaporan Segmen. Pelaporan Segmen adalah pelaporan keuangan khusus yang relevan bagi perusahaan yang memiliki diversifikasi usaha baik secara operasional maupun geografis. Diversifikasi usaha pada umumnya terdapat pada perusahaan berskala besar di mana manajer bermaksud untuk memperluas pangsa pasar sehingga dilakukan perluasan unit bisnis usaha ataupun memperluas wilayah bisnis. Untuk melihat efisiensi masingmasing segmen atau divisi yang ada maka manajer perlu memperhatikan laporan masingmasing segmen yang ada.

Pelaporan segmen menunjukkan informasi mengenai imbalan dan risiko dari masing-masing divisi perusahaan yang tidak dapat diperoleh dari data agregat. Artinya, bahwa laporan keuangan agregat tidak dapat menunjukkan secara rinci mengenai imbalan dan risiko masing-masing segmen. Dengan demikian, pelaporan segmen dianggap perlu dan dibutuhkan oleh manajer dalam menilai efisiensi dan efektivitas setiap segmen perusahaan.

Tidak adanya pengungkapan segmen tambahan seperti segmen geografis dan segmen operasi akan memengaruhi pemahaman dan penilaian laba segmen oleh investor non profesional. Pelaporan segmen berguna untuk mengetahui rincian kegiatan operasi dan kinerja keuangan suatu perusahaan selama tahun berjalan. Dengan melaporkan segmen, hal ini membuktikan bahwa perusahaan transparan dan akuntabel terhadap laporan keuangannya (Suryandari dan Arisanti, 2017).

Ruang lingkup pelaporan segmen sebagaimana tertulis dalam PSAK 5 adalah semua entitas publik (semua perusahaan yang terdaftar di BEI) dan entitas yang sedang dalam proses go public atau yang mengajukan pernyataan pendaftaran. Informasi segmen hanya dituangkan dalam laporan keuangan konsolidasian perusahaan.

Dalam menetapkan segmen usaha, ada beberapa alternatif guna menghasilkan informasi yang relevan dan signifikan terhadap investor, yaitu: 1). Divisi geografis, didasarkan pada wilayah geografis yang membedakan antara operasi domestik dan luar negeri, 2). Divisi lini produk atau industrial, untuk memahami lebih rinci mengenai imbalan dan risiko serta peluang pertumbuhan, 3). Divisi berdasarkan struktur intern pengendalian manajemen, yaitu mengumpulkan data yang akurat dengan biaya tambahan terkecil.

Segmen Operasi. Menurut PSAK 5 (SAK, 2014), tertulis bahwa segmen operasi adalah komponen perusahaan yang dapat dibedakan dalam menghasilkan produk atau jasa (baik produk atau jasa individual maupun kelompok produk atau jasa terkait) dan komponen itu memiliki risiko dan imbalan yang berbeda dengan risiko dan imbalan segmen lain. Terdapat beberapa faktor yang dipertimbangkan dalam menentukan terkait atau tidaknya produk atau jasa, diantaranya: 1). Karakteristik produk atau jasa, 2). Karakteristik proses produksi, 3). Jenis atau golongan pelanggan (jasa produk atau jasa), 4). Metode pendistribusian produk atau penyediaan.

Perusahaan yang memiliki segmen operasi pada umumnya memisahkan antara divisi usaha yang satu dengan lainnya. Contohnya, jasa perbankan, mungkin membedakan antara divisi perbankan dan kartu kredit dengan divisi kredit pemilikan rumah (KPR) atau kredit pemilikan apartemen (KPA), juga dengan divisi kredit tanpa agunan (KTA) atau kredit dengan agunan, dan lain sebagainya. Dengan ini tentunya manajer dapat lebih memahami 
secara rinci mengenai profit, risiko dan peluang pertumbuhan di masa mendatang masingmasing segmen. Juga, dalam mengambil keputusan untuk merencanakan strategi bisnis apa yang perlu diambil untuk mengembangkan suatu segmen, atau dalam mempertahankan atau mengeliminasi suatu segmen dari perusahaan.

Segmen Geografis. Menurut PSAK 5 (SAK, 2014), Segmen Geografis adalah komponen perusahaan yang dapat dibedakan dalam menghasilkan produk atau jasa pada lingkungan (wilayah) ekonomi tertentu dan komponen itu memiliki risiko dan imbalan yang berbeda dengan risiko dan imbalan pada komponen yang beroperasi pada lingkungan (wilayah) ekonomi lain.

Faktor-faktor yang perlu dipertimbangkan dalam mengidentifikasi segmen geografis: 1). Kesamaan kondisi ekonomi dan politik, 2). Hubungan antar operasi dalam wilayah geografis berbeda, 3). Kedekatan geografis operasi, 4). Risiko khusus yang terdapat dalam operasi di wilayah tertentu, 5). Regulasi pengendalian mata uang, 6). Risiko mata uang.

Faktor-faktor ini menekankan bahwa dalam menetapkan segmen geografisnya perusahaan perlu melihat berbagai kondisi yang ada, bukan semata-mata membedakan segmen geografis yang satu dengan lainnya hanya atas dasar perbedaan lingkungan (wilayah). Cakupan segmen geografis yang dimaksud tidak hanya secara internasional, tetapi juga negara bagian, wilayah, provinsi, kota atau lingkungan rumah tangga.

Pengembangan Hipotesis. Shadish et al. (2002) menyatakan sebuah hipotesis yaitu hipotesis transparansi yang mengaitkan antara diversifikasi dengan manajemen laba. Penelitian ini menunjukkan bahwa perusahaan yang terdiversifikasi memiliki tingkat asimetri informasi yang lebih tinggi dan kurang transparan jika dibandingkan dengan perusahaan yang tidak terdiversifikasi, karena mereka memiliki struktur yang lebih kompleks. El Mehdi dan Seboui (2011) sependapat dengan Shadish et al. (2002) menyebutkan bahwa diversifikasi dapat memperkuat asimetri informasi, menyebabkan keragaman budaya, dan mendorong misalokasi investasi. Hal ini menyebabkan manajer dapat mengeksploitasi asimetri informasi dengan melakukan manajemen laba.

Chin et al. (2009) menyatakan bahwa internasionalisasi perusahaan yang lebih tinggi berhubungan dengan manajemen laba yang lebih agresif. Dengan peningkatan penyebaran geografis perusahaan, akan meningkatkan kompleksitas organisasi, dan kemudian meningkatkan asimetri informasi antara manajer dan investor (Indraswari 2010).

Penelitian Verawati (2012) menemukan bahwa segmen operasi tidak berpengaruh terhadap manajemen laba namun segmen geografis berpengaruh terhadap manajemen laba. Penelitian Purnamaningtyas (2010) menunjukkan bahwa diversifikasi usaha memiliki pengaruh terhadap manajemen laba. Nugraheni (2011) berhasil membuktikan pengaruh negatif segmen geografis terhadap manajemen laba dan pengaruh positif segmen operasi terhadap manajemen laba.

Hasil penelitian Aryati dan Walansendouw (2013) menunjukkan bahwa tingkat diversifikasi perusahaan yang diproksikan dengan Indeks Herfindahl tidak berpengaruh terhadap manajemen laba yang diproksikan dengan discretionary current accruals. Penelitian yang dilakukan oleh Lupitasari dan Marsono (2012) membuktikan hal berikut ini. Diversifikasi operasi tidak berpengaruh terhadap manajemen laba pada perusahaan pertambangan dan perusahaan perbankan. Diversifikasi geografis berpengaruh negatif terhadap manajemen laba pada perusahaan pertambangan dan berpengaruh positif terhadap manajemen laba pada perusahaan perbankan. Diversifikasi operasi tidak 
mempengaruhi manajemen laba, sedangkan diversifikasi geografis berpengaruh positif. Hasil ini diperoleh dari penelitian Kusumayani dan Wirama (2016). Penelitian Dimarcia dan Krisnadewi (2016) menunjukkan hasil bahwa diversifikasi operasi tidak berpengaruh pada manajemen laba. Menurut Dinuka dan Zulaikha (2014), faktor diversifikasi geografis tidak berpengaruh terhadap manajemen laba.

Pada hakekatnya, sebuah perusahaan yang terdiversifikasi dan menyusun laporan segmental akan memiliki kompleksitas yang lebih tinggi daripada perusahaan yang hanya menerbitkan laporan keuangan konsolidasian. Perusahaan dengan banyak divisi akan meningkatkan kompetisi atau daya saing antar divisi untuk memperlihatkan divisi mana yang memberikan kontribusi profit terbanyak pada agregat perusahaan. Dalam rangka mencapai salah satu tujuan ini, manajer divisi akan berupaya meningkatkan pencapaian profit divisi yang dipimpinnya didukung dengan kompleksitas tersebut, dengan demikian manajemen laba dapat dilakukan.

Berdasarkan teori yang ada maka hipotesis yang diajukan adalah :

$\mathrm{H}_{1}$ Pelaporan segmen operasi memiliki pengaruh positif terhadap manajemen laba.

$\mathrm{H}_{2}$ Pelaporan segmen geografis memiliki pengaruh positif terhadap manajemen laba.

\section{Model Penelitian}

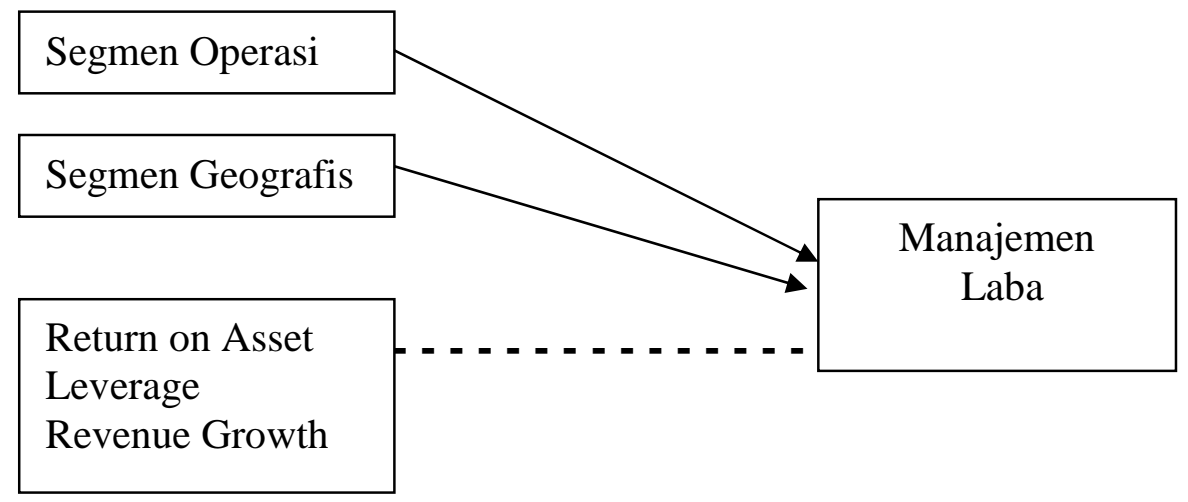

\section{METODE}

Metode sampling yang digunakan dalam penelitian ini adalah metode purposive sampling. Metode purposive sampling merupakan teknik pengambilan sampling sesuai dengan kriteria tertentu yang disesuaikan dengan tujuan penelitian. Adapun kriteria yang digunakan dalam penelitian ini adalah: 1). Perusahaan manufaktur yang terdaftar di Bursa Efek Indonesia pada tahun 2011 - 2013, 2). Perusahaan konsisten mempublikasikan laporan keuangan dengan satuan mata uang Rupiah, 3). Perusahaan yang konsisten memperoleh laba selama periode 2011-2013, 4). Perusahaan yang konsisten menerbitkan laporan keuangan yang berakhir pada 31 Desember.

Pertimbangan pemilihan perusahaan sektor manufaktur adalah karena sektor manufaktur merupakan sektor perusahaan di BEI dengan jumlah paling banyak dan umumnya memiliki segmen operasi maupun geografis. 
Metode Pengumpulan Data. Data yang digunakan dalam penelitian ini adalah data sekunder. Data sekunder dalam penelitian ini adalah laporan keuangan tahun 2011 - 2013. Laporan keuangan yang dimaksud diperoleh dari situs BEI http://www.idx.co.id dengan melihat pembagian sektor pada situs Saham OK http://www.sahamok.com.

Definisi Operacional. Variabel Independen: Segmen Operasi dan Segmen Geografis. Variabel segmen operasi dan segmen geografis adalah variabel independen. Masingmasing segmen diukur dengan jumlah segmen yang dilapor perusahaan. Bila perusahaan hanya memiliki satu segmen baik operasi maupun geografis maka nilai segmen masingmasing adalah sebesar 1 . Namun bila perusahaan melaporkan hasil operasinya dari berbagai segmen maka nilai segmen adalah sejumlah segmen operasi maupun geografis yang dilaporkannya.

Variabel Dependen: Manajemen Laba. Variabel manajemen laba adalah variabel dependen. Pengukuran variabel ini akan mengacu pada conditional revenue model yang dikembangkan oleh Stubben (2010). Stubben (2010) menyatakan bahwa penggunaan model ini dapat mengukur manajemen laba dengan lebih baik dibandingkan dengan pendekatan akrual. Formula atas conditional revenue model seperti yang digunakan dalam penelitian ini adalah sebagai berikut:

$$
\begin{gathered}
A R_{i t}=\alpha+\beta_{1} R_{i t}+\beta_{2} R_{i t} \times S I Z E_{i t}+\beta_{3} R_{i t} \times A G E_{i t}-\beta_{4} R_{i t} \times A G E_{-} S Q_{i t}- \\
\beta_{5} R_{i t} \times G R R \_P_{i t}+\beta_{6} R_{i t} \times G R R \_N_{i t}+\beta_{7} R_{i t} \times G R M_{i t}+\beta_{8} \quad R_{i t} \times G R M \_S Q_{i t}+e_{i t}
\end{gathered}
$$

Dimana: $\mathrm{AR}_{\mathrm{it}}=$ Accounts Receivable (piutang) perusahaan i pada tahun $\mathrm{t} ; \mathrm{R}_{\mathrm{it}}=$ Revenue (pendapatan) perusahaan i pada tahun; $\mathrm{SIZE}_{\mathrm{it}}=\mathrm{Log}$ natural dari ukuran perusahaan (total asset) pada akhir tahun; $\mathrm{AGE}_{\mathrm{it}}=$ Umur perusahaan (dalam tahun); GRR_P $\mathrm{P}_{\mathrm{it}}=$ industrymedian-adjusted revenue growth (=0 if negative); GRR_ $\mathrm{N}_{\mathrm{it}}=$ industry-median-adjusted revenue growth ( $=0$ if positive); GRM = industry-median-adjusted gross margin at end of fiscal year; _SQ = square of variable $; \quad=$ annual change (perubahan tahunan); $e_{\mathrm{it}}=$ the error term.

Penjelasan mengenai formula conditional revenue model adalah sebagai berikut:

1. R/Perubahan Pendapatan. Merupakan perubahan pendapatan tahun sekarang dengan tahun sebelumya.

$$
\mathrm{R}=\text { Pendapatan }_{\mathrm{t}}-\text { Pendapatan }_{\mathrm{t}-1}
$$

2. Size. Merupakan natural log atas total asset sebagai ukuran perusahaan.

3. Age. Merupakan umur perusahaan dalam satuan tahun, diperoleh dari perhitungan sejak tahun perusahaan berdiri sampai dengan tahun yang bersangkutan

4. Growth Rate in Revenue (GRR). Merupakan persentase pendapatan (revenue) perusahaan tahun berjalan dengan tahun sebelumnya. GRR terdiri atas GRR_P, yaitu jika GRR bernilai negatif maka sama dengan 0 dan GRR_N, yaitu jika GRR bernilai positif maka sama dengan 0 . 
Pendapatan $_{t}-$ pendapatan $_{\mathrm{t}-1}$

Pendapatan $_{\mathrm{t}-1}$

5. Gross Margin (GRM). Diperoleh dengan membagi laba kotor (gross profit) dengan pendapatan (revenue).

Variabel Kontrol. Variabel kontrol yang digunakan dalam penelitian ini adalah Return on Assets (ROA), Leverage, dan Revenue Growth.

Return on Assets (ROA). Return on Assets (ROA) adalah rasio yang menunjukkan kemampuan perusahaan dalam menghasilkan laba dalam satu periode tertentu dengan memanfaatkan seluruh asset yang dimilikinya. Dengan demikian, semakin tinggi rasio ini, maka akan semakin baik bagi perusahaan. Return On Asset (ROA) merefleksikan seberapa banyak perusahaan telah memperoleh hasil atas sumber daya keungan yang ditanamkan oleh perusahaan. (Munawir, 2010). Untuk menghitung Return on Assets (ROA), digunakan rumus seperti berikut ini:

$$
\mathrm{ROA}=\frac{\text { Net Income }}{\text { Total Asset }}
$$

Leverage. Leverage adalah rasio yang digunakan untuk mengukur seberapa besar asset perusahaan dibiayai oleh hutang. Rasio leverage yang digunakan dalam penelitian ini adalah debt ratio (Jao dan Pagalung, 2011). Untuk menghitung rasio ini, digunakan rumus sebagai berikut:

$$
\text { Leverage }=\frac{\text { Total Liabilitas }}{\text { Total Asse } \mathrm{t}}
$$

Revenue Growth. Revenue Growth merupakan pertumbuhan pendapatan tahun sekarang dibandingkan dengan tahun sebelumnya (Handayani dan Rachadi, 2009). Angka ini dinyatakan dalam persentase, dengan rumus sebagai berikut:

$$
\text { Revenue Growth }=\frac{\text { Revenue }- \text { Revenue } t-1}{\text { Revenue } t-1}
$$

Metode Analisis Data. Model regresi yang digunakan adalah sebagai berikut:

$$
E M_{i t}=\alpha+\beta_{1} S O P_{i t}+\beta 2 S G E O_{i t}+\beta_{3} R O A_{i t}+\beta_{4} L E V_{i t}+\beta_{5} G R O W T H_{i t}+e_{i t}
$$

Dimana: $\mathrm{EM}_{\mathrm{it}}=$ Earnings Management (Manajemen Laba) perusahaan pada tahun t; $\mathrm{SOP}_{\mathrm{it}}=$ Segmen Operasi yang dilaporkan perusahaan i pada tahun $\mathrm{t} ; \mathrm{SGEO}_{\mathrm{it}}=$ Segmen Geografis yang dilaporkan perusahaan i pada tahun t.; $\mathrm{ROA}_{\mathrm{it}}=$ Return on Assets, dihitung dengan rumus net income dibagi dengan total asset perusahaan i pada tahun t.; $L_{E V}$ it $=$ Leverage, dihitung dengan rumus total liabilitas dibagi dengan total asset perusahaan i 
pada tahun t.; GROWTH $\mathrm{G}_{\mathrm{it}}=$ Revenue Growth, persentase pertumbuhan pendapatan perusahaan pada tahun $\mathrm{t}$ terhadap tahun $\mathrm{t}-1$; $\mathrm{e}_{\mathrm{it}}=$ error .

\section{HASIL DAN PEMBAHASAN}

Deskripsi Obyek Penelitian. Pada tabel berikut ini terlihat proses pemilihan sampel berdasarkan kriteria yang telah ditetapkan sebelumnya.

Tabel 1. Data Hasil Pemilihan Sampel

\begin{tabular}{lc}
\hline \multicolumn{1}{c}{ Uraian } & Jumlah \\
\hline $\begin{array}{l}\text { Perusahaan manufaktur konsisten terdaftar di Bursa Efek Indonesia periode } \\
\text { 2011-2013. }\end{array}$ & 122 \\
$\begin{array}{l}\text { Perusahaan tidak konsisten mempublikasikan laporan keuangan dengan satuan } \\
\text { mata uang Rupiah. }\end{array}$ & $(20)$ \\
$\begin{array}{l}\text { Perusahaan tidak konsisten memperoleh laba. } \\
\text { Perusahaan tidak konsisten menerbitkan laporan keuangan yang berakhir pada }\end{array}$ & $(32)$ \\
31 Desember. & $\underline{(4)}$ \\
Total perusahaan & 66 \\
Total data penelitian 3 tahun & $\underline{198}$ \\
\hline
\end{tabular}

Statistik Deskriptif. Statistik deskriptif dari setiap variabel dapat dilihat pada tabel berikut ini:

Tabel 2. Hasil Statistik Deskriptif

\begin{tabular}{lcrrrr}
\hline \multicolumn{1}{c}{ Variabel } & $\mathrm{N}$ & \multicolumn{1}{c}{ Minimum } & \multicolumn{1}{c}{ Maximum } & \multicolumn{1}{c}{ Mean } & \multicolumn{1}{c}{ Std. Deviation } \\
\hline EM & 198 & $-66281,560$ & $3,76429 \mathrm{E} 6$ & $1,5586353 \mathrm{E}$ & $4,36685089 \mathrm{E} 5$ \\
GEO & 198 & 1,000 & 27,000 & 3,616 & 3,937 \\
OP & 198 & 1,000 & 8,000 & 2,889 & 1,596 \\
GRW & 198 & $-0,580$ & 1,490 & 0,161 & 0,204 \\
ROA & 198 & 0,000 & 0,420 & 0,010 & 0,085 \\
LEV & 198 & 0,040 & 0,880 & 0,425 & 0,179 \\
\hline
\end{tabular}

Hasil Uji Kualitas Data. Uji Normalitas. Hasil uji normalitas dengan menggunakan uji Kolmogorov-Smirnov (K-S) menunjukkan nilai Asymp. Sig. (2-tailed) sebesar 0,780 yang menunjukkan bahwa residual pada model regresi memiliki pola distribusi normal karena telah memenuhi syarat uji normalitas yaitu lebih besar daripada 0,050 .

Hasil Uji Asumsi Klasik. Uji Multikolonieritas. Berikut adalah hasil dari pengujian multikolonieritas yang telah dilakukan dalam penelitian ini: 
Tabel 3. Hasil Uji Multikolonieritas

\begin{tabular}{cccc}
\hline & \multicolumn{2}{c}{ Collinearity Statistics } & \\
Variabel & Tolerance & VIF & Catatan \\
\hline GEO & 0,980 & 1,021 & Tidak ada masalah multikolonieritas \\
OP & 0,873 & 1,145 & Tidak ada masalah multikolonieritas \\
GRW & 0,929 & 1,076 & Tidak ada masalah multikolonieritas \\
ROA & 0,865 & 1,156 & Tidak ada masalah multikolonieritas \\
LEV & 0,795 & 1,257 & Tidak ada masalah multikolonieritas \\
\hline
\end{tabular}

Uji Heteroskedastisitas. Berikut adalah hasil dari pengujian heteroskedastisitas yang telah dilakukan dalam penelitian ini:

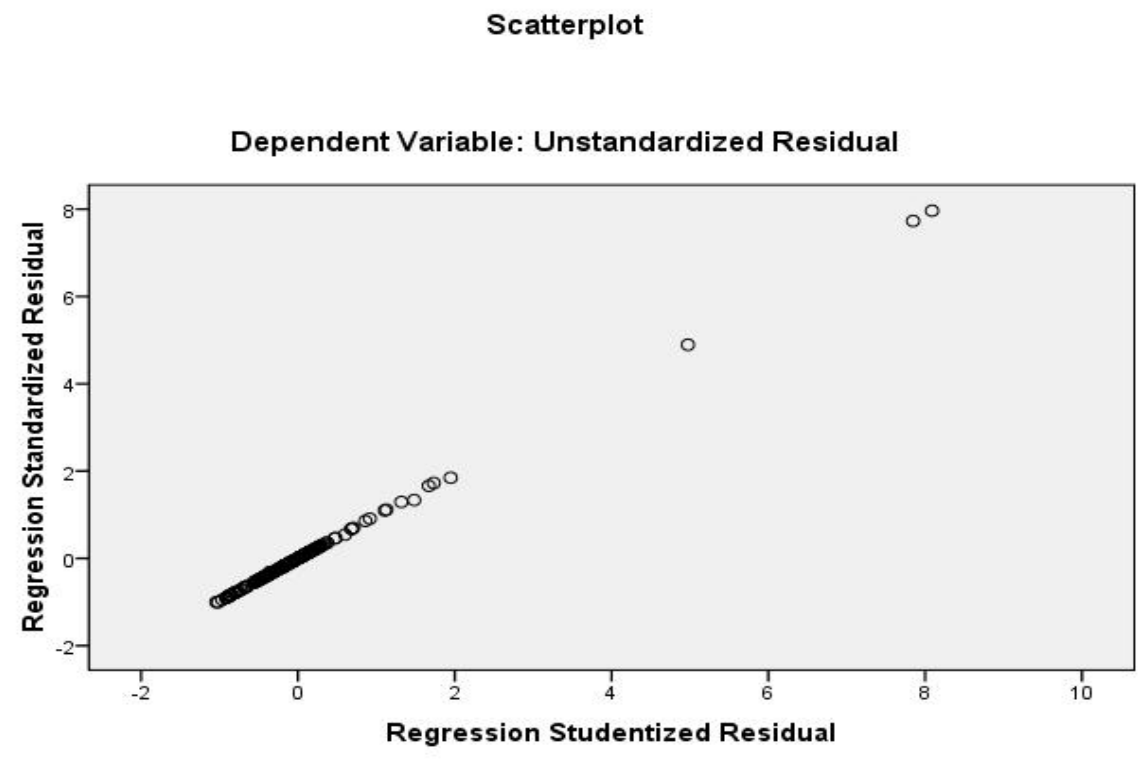

Gambar 1. Hasil Uji Heteroskedastisitas

Berdasarkan Gambar 1 di atas, dapat dilihat bahwa sebaran data membentuk pola sehingga dapat dikatakan terdapat masalah heteroskedastisitas.

Uji Autokorelasi. Berikut adalah hasil dari pengujian autokorelasi yang telah dilakukan dalam penelitian ini. Nilai Durbin-Watson dari hasil uji autokorelasi adalah sebesar 0.718 yang menunjukan bahwa nilai tersebut tidak berada di antara nilai du $(1,7159)$ dan 4-du (4-1,7159); yang didapat dari tabel Durbin-Watson. Dengan demikian, dapat disimpulkan bahwa dalam model regresi terdapat adanya autokorelasi. 


\section{Hasil Uji Hipótesis. Koefisien Korelasi (R) dan Koefisien Determinasi (Adjusted $\boldsymbol{R}^{2}$ )}

Tabel 4. Hasil Uji Koefisien Korelasi dan Koefisien Determinasi

\begin{tabular}{rrrrr}
\hline Model & & \multicolumn{2}{l}{ R } & \multicolumn{2}{c}{ R Square } & \multicolumn{2}{c}{ Adjusted R Square } \\
\hline & 1 & 0,354 & 0,125 & 0,102 \\
\hline
\end{tabular}

Dari Tabel di atas, nilai $\mathrm{R}$ yang dihasilkan adalah sebesar 0,354 yang berarti bahwa hubungan antara segmen geografis dan operasi dengan manajemen laba adalah sebesar 0,354 . Angka ini menunjukkan adanya korelasi yang lemah karena lebih kecil daripada 0,5. Selain itu, pada tabel di atas dapat dilihat pula bahwa nilai koefisien determinasi yang ditunjukkan dengan nilai Adjusted $R^{2}$ yang dihasilkan adalah sebesar 0,102 atau 10,2\%. Hal ini menunjukkan bahwa variasi variabel dependen yakni manajemen laba yang dapat dijelaskan oleh variasi variabel independen yaitu segmen geografis dan operasi adalah sebesar $10,2 \%$, sedangkan sisanya sebesar $89,8 \%$ dijelaskan oleh faktor lain yang tidak dimasukkan dalam penelitian ini.

\section{Uji F}

Tabel 5. Hasil Uji F

\begin{tabular}{llcrrrr}
\hline & & \multicolumn{2}{c}{ Sum of } & \multicolumn{2}{c}{ Mean } \\
\multicolumn{1}{c}{ Model } & Squares & \multicolumn{1}{c}{ df } & \multicolumn{1}{c}{ Square } & \multicolumn{1}{c}{ F } & \multicolumn{1}{c}{ Sig. } \\
\hline 1 & Regression & $4,698 \mathrm{E} 12$ & 5 & 0,000 & 5,489 &, 000 \\
& Residual & $3,287 \mathrm{E} 13$ & 192 & 0,000 & & \\
& Total & $3,757 \mathrm{E} 13$ & 197 & & & \\
\end{tabular}

Dari Tabel di atas, dapat dilihat bahwa nilai $\mathrm{F}$ hitung yang dihasilkan adalah sebesar 5,489 dengan tingkat probabilitas signifikansi sebesar 0,000. Karena nilai probabilitas signifikansi tersebut jauh di bawah nilai alpha 5\%, maka dapat disimpulkan bahwa model regresi secara keseluruhan yang digunakan sudah layak.

\section{Uji Regresi Parsial (Uji t)}

Tabel 6. Hasil Uji Regresi Parsial (Uji t)

\begin{tabular}{|c|c|c|c|c|c|}
\hline \multirow[t]{2}{*}{ Model } & \multicolumn{2}{|c|}{ Unstandardized Coefficients } & \multirow{2}{*}{$\begin{array}{l}\text { Standardized } \\
\text { Coefficients } \\
\text { Beta }\end{array}$} & \multirow[t]{2}{*}{$\mathrm{t}$} & \multirow[t]{2}{*}{ Sig. } \\
\hline & B & Std. Error & & & \\
\hline (Constant) & $-0,25$ & 107965,598 & & $-2,364$ & ,019 \\
\hline GEO & 0,14 & 7566,000 & ,013 & , 185 & ,853 \\
\hline $\mathrm{OP}$ & 0,86 & 19771,912 & 317 & 4,384 & ,000 \\
\hline GRW & $-0,30$ & 150123,842 &,- 014 &,- 202 & 840 \\
\hline ROA & 0,10 & 371415,187 &, 213 & 2,941 & ,004 \\
\hline LEV & 0,12 & 184869,508 &, 050 & ,655 & ,513 \\
\hline
\end{tabular}


Dari Tabel 6 di atas dapat diketahui pula bahwa nilai signifikansi dari variabel segmen geografis adalah sebesar 0,853 dan nilai tersebut berada di atas 0,05 yang berarti bahwa variabel segmen geografis tidak memiliki pengaruh terhadap manajemen laba. Sedangkan untuk variabel segmen operasi diketahui bahwa nilai signifikansi sebesar 0,000 . Berbeda dengan variabel segmen geografis, variabel ini memiliki nilai di bawah 0,005 yang berarti variabel segmen operasi memiliki pengaruh yang signifikan dan bernilai positif terhadap manajemen laba dengan nilai koefisien 0,86 .

Hasil penelitian ini menunjukkan bahwa jumlah segmen geografis di dalam perusahaan tidak berpengaruh terhadap manajemen laba. Berdasarkan hasil pengujian yang telah dilakukan, penelitian ini membuktikan bahwa tidak ada keterkaitan antara jumlah segmen yang dilaporkan perusahaan berdasarkan lokasi geografisnya terhadap tindak manajemen laba yang dilakukan. Hasil penelitian ini tidak konsisten dengan penelitian Verawati (2012), Purnamaningtyas (2010), dan Nugraheni (2011). Jumlah segmen operasi pada penelitian ini berpengaruh positif terhadap manajemen laba, artinya semakin banyak perusahaan melaporkan segmen operasinya, maka akan semakin besar pula nilai manajemen laba dari perusahaan itu sendiri. Hal ini sesuai dengan teori yang ada bahwa semakin banyak suatu perusahaan terdiversifikasi atau membagi dan melaporkan segmen usahanya, semakin tinggi pula kompleksitas dan daya saing antar segmen tersebut sehingga pada akhirnya dapat meningkatkan terjadinya manajemen laba. Hasil ini tidak konsisten dengan penelitian Verawati (2012) namun konsisten dengan penelitian Purnamaningtyas (2010) dan Nugraheni (2011).

Selain itu, hasil penelitian ini menunjukkan bahwa variabel kontrol revenue growth tidak memiliki pengaruh terhadap manajemen laba. Semakin besar pertumbuhan pendapatan suatu perusahaan tidak berarti semakin banyak tindakan manajemen laba yang dilakukan. Sedangkan untuk variabel return on assets memiliki pengaruh terhadap manajemen laba. Semakin besar nilai return on assets sebuah perusahaan, semakin tinggi pula tingkat manajemen laba yang dilakukan. Untuk variabel kontrol yang terakhir, leverage, tidak terbukti memiliki pengaruh terhadap manajemen laba.

\section{PENUTUP}

Simpulan. Dari hasil penelitian pengaruh diversifikasi usaha yang diproksi ke dalam pelaporan segmen geografis maupun operasi sebagaimana diatur secara tertulis dalam PSAK 5, terhadap manajemen laba dari perusahaan - perusahaan manufaktur yang terdaftar di Bursa Efek Indonesia, maka dengan ini dapat disimpulkan bahwa diversifikasi usaha tidak terbukti signifikan mempengaruhi manajemen laba. Hal ini didukung dengan nilai Adjusted $\mathrm{R}^{2}$ yang cukup rendah yang menggambarkan bahwa dari variabel - variabel yang digunakan (termasuk variabel kontrol, yaitu revenue growth, return on assets, dan leverage) tidak terbukti secara signifikan mempengaruhi manajemen laba, artinya ada faktor-faktor lain yang secara lebih signifikan mempengaruhi tinggi atau rendahnya praktik manajemen laba dalam perusahaan. Hasil penelitian ini membuktikan bahwa diverisifikasi usaha yang diproksi dengan segmen geografis tidak berpengaruh terhadap manajemen laba, tidak sejalan dengan penelitian yang dilakukan oleh Nugraheni (2011) yang mana dari hasil penelitian yang dilakukan menyatakan bahwa penerapan segmen geografis berpengaruh negatif terhadap manajemen laba. Akan tetapi, untuk varabel bebas kedua yang diproksi sebagai segmen operasi terbukti sejalan dengan penelitian yang 
dilakukan oleh Nugraheni (2011), yaitu penerapan pelaporan segmen operasi terbukti berpengaruh positif terhadap manajemen laba.

Implikasi Hasil Penelitian. Hasil penelitian ini diharapkan memiliki beberapa implikasi untuk berbagai kepentingan, terutama kepada pihak perusahaan dan Ikatan Akuntan Indonesia (IAI) sebagai pihak yang menetapkan regulasi akuntansi di Indonesia. Pihak perusahaan diharapkan dapat menjadikan penerapan PSAK 5 ini sebagai salah satu pertimbangan dalam keterkaitannya terhadap manajemen laba. Sehingga pelaporan segmen yang diterbitkan oleh perusahaan tidak semata-mata untuk memenuhi standar akuntansi yang ada, akan tetapi juga menjadi pertimbangan dalam hal praktik manajemen laba dalam perusahaan itu sendiri. Bagi IAI, berdasarkan hasil penelitian ini serta penelitian-penelitian terdahulu yang memberikan hasil yang beranekaragam, maka dapat menjadi suatu input bahwa penerapan PSAK 5 terkait pelaporan segmen baik geografis maupun operasi dapat dikatakan tidak secara signifkan mempengaruhi praktik manajemen laba. Dengan demikian, untuk mengontrol tinggi rendahnya praktik manajemen perusahaan-perusahaan di Indonesia, dapat diberikan atribut-atribut lain dalam PSAK sesuai dengan tujuan yang dikehendaki.

Keterbatasan Penelitian. Penelitian ini tentunya memiliki berbagai keterbatasan. Sehingga perlu pertimbangan dan kehati-hatian dalam menginterpretasikan hasil penelitian ini sendiri. Keterbatasan penelitian ini adalah hanya mengambil segmen geografis dan segmen operasi sebagai variabel independen dengan revenue growth, return on assets dan leverage sebagai variabel kontrol penelitian. Dengan Adjusted $\mathrm{R}^{2}$ sebesar $10,2 \%$, disimpulkan bahwa masih terdapat banyak faktor lain yang dapat menjelaskan manajemen laba yang dilakukan oleh perusahaan.

Saran. Mengacu pada keterbatasan yang ada maka saran yang dapat diberikan adalah meneliti lebih lanjut variabel lain yang memiliki pengaruh terhadap manajemen laba seperti nilai perusahaan, praktek corporate governance, dan faktor-faktor lainnya.

\section{DAFTAR RUJUKAN}

Aryati, Titik dan Yoel Charisma Walansendouw. (2013) "Analisis Pengaruh Diversifikasi Perusahaan terhadap Manajemen Laba". Jurnal Akuntansi \& Auditing, 9 (2), 244 260.

Chin, C.L, Y.J. Chen, dan T.J. Hsieh. (2009) "International Diversification, Ownership Structure, Legal Origin and Earnings Management: Evidence from Taiwan”. Journal of Accounting, Auditing and Finance, 24, 233 - 362.

Dimarcia, Ni Luh Floriani Ria dan Komang Ayu Krisnadewi. (2016) "Pengaruh Diversifikasi Operasi, Leverage, dan Kepemilikan Manajerial pada Manajemen Laba". E-Jurnal Akuntansi Universitas Udayana, 15 (3), 2324-2351.

Dinuka, Vina Kholisa dan Zulaikha. (2014) "Analisis Pengaruh Audit Tenure, Ukuran KAP, Diversifikasi Geografis terhadap Manajemen Laba”. Diponegoro Journal of Accounting, 3 (3). Diakses melalui http://ejournals1.undip.ac.id/index.php/accounting.

El Mehdi, I.K., dan S. Seboui. (2011) "Corporat Diversification and Earnings Management". Review of Accounting and Finance, 10 (2), 176 - 196. 
Handayani, RR Sri dan Agustono Dwi Rachadi. (2009) "Pengaruh Ukuran Perusahaan terhadap Manajemen Laba". Jurnal Bisnis dan Akuntansi, 11 (1), 33-56.

Harto, Puji. (2005) "Kebijakan Diversifikasi Perusahaan dan Pengaruhnya Terhadap Kinerja: Studi Empiris pada Perusahaan Publik di Indonesia”. Jurnal Akuntansi dan Keuangan, 1, 297-307.

Ikatan Akuntan Indonesia. (2014) Standar Akuntansi Keuangan per Efektif 1 Januari 2015. Cetakan Pertama. Jakarta: Ikatan Akuntan Indonesia.

Indraswari, Ratih. (2010) Pengaruh Status Internasional, Diversifikasi Operasi dan Legal Origin terhadap Manajemen Laba (Studi Perusahaan Asia yang Terdaftar di NYSE). Simposium Nasional Akuntansi (SNA) XIII. Purwokerto.

Jao, Robert dan Gagaring Pagalung. (2011) "Corporate Governance, Ukuran Perusahaan, dan Leverage terhadap Manajemen Laba Perusahaan Manufaktur Indonesia”. Jurnal Akuntansi \& Auditing, 8 (1).

Jensen, M. C and Meckling, W.H. (1976) "Theory of the Firm : Managerial Behavior, Agency Costs and Ownership Structure". Journal of Financial Economics, 3 (4), 305 - 360. Homepage Online. Available from http://papers.ssrn.com; Internet; accessed 14 April 2014.

Kusumayani, Ni Luh dan Dewa Gede Wirama. (2016) "Good Corporate Governance sebagai Pemoderasi Pengaruh Diversifikasi Operasi dan Diversifikasi Geografis pada Manajemen Laba". E-Jurnal Akuntansi Universitas Udayana, 14 (3), 20722102.

Lupitasari, Dewi dan Marsono. (2012) "Diversifikasi Perusahaan dan Manajemen Laba". Diponegoro Journal of Accounting, 1 (1). Diakses melalui http://ejournals1.undip.ac.id/index.php/accounting.

Michelson, S.E., J.J. Wagner and C.W. Wootton. (1995) "A Market Based Analysis of Income Smoothing”. Journal of Business Finance and Accounting, pp. 1179 - 1193.

Munawir, Slamet. (2010) Analisa Laporan Keuangan. Yogyakarta: Liberty.

Nugraheni, Rewita. (2011) "Pengaruh Segment Reporting Terhadap Manajemen Laba (Studi Perusahaan Asia yang Terdaftar di NYSE)". Publikasi melalui website Universitas Atma Jaya Yogyakarta.

Purnamaningtyas, Arum Endah. (2010) "Pengaruh Diversifikasi Usaha Terhadap Manajemen Laba". Publikasi melalui website Universitas Atma Jaya Yogyakarta.

Rahmawati. (2006) "Pengaruh Asimetri Informasi pada Hubungan antara Regulasi Perbankan dan Manajemen Laba serta Dampaknya Terhadap Kinerja Saham (Studi Empiris pada Industri Perbankan di Indonesia)". Electronic Theses \& Dissertations Universitas Gadjah Mada.

Scott, W.R. (2011) Financial Accounting Theory. $6^{\text {th }}$ edition. Pearson.

Shadish, W.R., Thomas D.C., dan Donald T.C. (2002) Experimental and QuasiExperimental Designs for Generalized Causal Inference. New York: Houghton Mifflin Company Boston.

Sri Sulistyanto. (2008) Manajemen Laba Teori dan Model Empiris. Jakarta: Grasindo.

Stubben, Stephen R. (2010) "Discretionary Revenues as a Measure of Earnings Management". Accounting Review, Volume 85, Issue 2.

Suryandari, Erni dan Imelda Puspita Arisanti. (2017) "Interpretasi Investor NonProfesional atas Implementasi International Financial Reporting Standard (IFRS) 8 dan Pernyataan Standar Akuntansi Keuangan (PSAK) 5 dalam Perspektif Framing Information". Jurnal Akuntansi dan Investasi, 18 (1), 128-140. 
Utami, Wiwik. (2005) "Pengaruh Manajemen Laba Terhadap Biaya Modal Ekuitas (Studi pada Perusahaan Manufaktur)". Simposium Nasional Akuntansi VII, pp. 100 - 116.

Verawati, Diana. (2012) Pengaruh Diversifikasi Operasi, Diversifikasi Geografis, Leverage dan Struktur Kepemilikan Terhadap Manajemen Laba (Studi Pada Perusahaan Manufaktur yang Terdaftar di Bursa Efek Indonesia tahun 2009 - 2010. Publikasi melalui Website Universitas Diponegoro.

Watts, R and Zimmerman. (1986) "Towards a Positive Theory of The Determination of Accounting Standards". Accounting Review, 53, 112-134. 